\title{
Internering og frigjøring
}

\author{
Hvorfor ble alle barna ved Grefsen sanatorium bronkoskopert? Hvorfor \\ fikk de i 1950-årene ikke besøk av foreldrene mer enn en gang i uken? \\ Hvorfor protesterte ikke vi leger mot denne behandlingen? I denne \\ kronikken diskuterer jeg disse ubehagelige spørsmålene.
}

\section{Kjell Bjartveit}

kjell.bjartveit@getmail.no

Fridtjof Nansens vei 24B

0369 Oslo

Det gjør vondt å lese Bjørn Oscar Hoftvedts barndomserindringer fra Grefsen sanatorium i dette nummer av Tidsskriftet (1). Hvorfor var forholdene slik - bare 55 år tilbake i tid?

Vi må gå ytterligere 55 år tilbake for å komme på sporet. I 1900 kulminerte tuberkulosedødeligheten i Norge. Med tilsvarende dødelighet i dag ville vi hatt nær 15000 tuberkulosedødsfall årlig. Myndighetenes svar på denne desperate situasjonen var bl.a. store, statsdrevne sanatorier hvor pasienter der det var håp om helbredelse kunne innlegges (2). Sanatoriene skulle sikre at også «fattige tæringssyke» fikk behandling. Den besto av frisk luft og rikelig næring. Modellen var et tysk sanatorium der man hadde oppnådd $13 \%$ fullstendig og $11 \%$ relativ helbredelse. Sanatoriene ble bygd med store verandaliknende kurhaller, hvor pasientene måtte ligge stille mange timer hver dag - til alle årstider og $i$ all slags vær. Behandlingen varte i måneder og år.

I årene etter 1910 ble kollapsbehandlingen tatt i bruk. Hensikten var å få de tuberkuløse kavernene til å klappe sammen. Først kom pneumothoraxbehandlingen, fra 1930-årene også torakoplastikken. Tusener av tuberkulosepasienter gjennomgikk denne smertefulle og mutilerende behandlingen, med holdningsendringer i rygg og nakke og ofte nedsatt lungefunksjon som resultat.

Men prognosen var fortsatt dårlig: Av nye tuberkulosepasienter som ble registrert ved Oslo helseråd i 1930-årene - og de fleste av dem var unge - var nær halvparten døde før det var gått åtte år.

Jeg var assistentlege ved Landeskogen sanatorium i 1953-55. Der ble det ikke innlagt barn. Inntrykkene er sterke av hvilke lidelser og savn også voksne tuberkulosepasienter måtte igjennom. En kvinne fortalte meg om velkomsten hun fikk da hun første gang ble innlagt i sanatoriet. Hun var 16 år gammel og kom derfor ikke til barnesanatorium. De fem andre pasientene på rommet lå skjult bak sine ukeblader. Etter en time tok den nærmeste bladet fra munnen: «Det første året er det verste,» sa hun og dukket ned bak ukebladet igjen. Vi kan knapt forestille oss pasientenes situasjon.

I slutten av 1940-årene kom de første tuberkulosemedikamentene. De ble opprinnelig brukt som supplement til hvilekur og kollapsbehandling. Men etter få år var dette snudd - medikamentene ble basis i tuberkulosebehandlingen. I begynnelsen av 1960årene hevdet en foredragsholder i Norsk selskap for tuberkulose og lungesykdommer at den medikamentelle behandling i stor utstrekning kunne skje ambulant. Jeg husker at dette ble for radikalt for tilstedeværende sanatorieoverleger. «Men hva med kuringen, da?» spurte en av dem bestyrtet.

\section{Barnetuberkulosen i 1950-årene}

I skoleåret 1953/54 var 2\% av førsteklassingene og $7 \%$ av sjuendeklassingene pirquetpositive (3). Det var på den tiden Hoftvedt ble smittet.

I 1950 ble det registrert 760 tilfeller av tuberkulose hos barn under 15 år. I 1954 var tallet gått ned til 595 og i 1959 til 311 tilfeller (fig 1) (Det sentrale tuberkuloseregister, Nasjonalt folkehelseinstitutt. Upublisert materiale, 2009). Hos barn opptrådte sykdommen som primærtuberkulose,

Men også barn døde av sykdommen. I femårsperioden 1951-55 døde 95 barn under 15 år av tuberkulose, i 1956-60 var det 11 dødsfall (4). Disse skyldtes oftest meningitt eller miliærtuberkulose, som fulgte i primærinfeksjonens kjølvann.

1.12. 1960 var det innlagt 239 barn under 15 år pga. tuberkulose i norske sykehus, fordelt med $117 \mathrm{i}$ sanatorier/lungeavdelinger, 48 i tuberkulosehjem, 53 i kysthospitaler og 21 i andre sykehus (5). 222 var innlagt for intratorakal tuberkulose og 17 for tuberkulose i andre organer. Ifølge Hoftvedt hadde Grefsen sanatorium et belegg på 40 barn, altså bare $18 \%$ av barna innlagt i sykehus pga. intratorakal tuberkulose.

\section{Overlegen ved Grefsen sanatorium}

På Grefsen sanatorium var overlege Simon Frostad (1903-84) sjef i årene 1953-72 i første rekke hilusadenitt.
(6). Han var en av forgrunnsfigurene i norsk tuberkulosemedisin. I en artikkel i Tidsskriftet redegjorde han i detalj for 223 barn i alderen 3 md.-14 år innlagt i sanatoriet i årene 1954-60 pga. primærtuberkulose (7).

Frostad sørget for grundige og systematiske utredninger av alle barna. «Samtlige barn - uten noen unntagelse og uten noen seleksjon - ble bronkoskopert uansett hvilken form for tuberkulose som forelå,» fremhevet han. Noen få av de største barna ble bronkoskopert i lokalanestesi ved sanatoriet, de øvrige ble undersøkt i narkose av øre-nese-hals-spesialist annetsteds. Det ble utført til sammen 934 bronkoskopier hos disse barna, 1-10 ganger hos hver enkelt. Det ble brukt stivt bronkoskop, dette var før de fleksible fiberbronkoskopenes tid.

Frostad er tydelig stolt av dette: «Materialet er sannsynligvis enestående i sitt slag,» skrev han. Senere sørget han også for at det ble utført bronkografi hos alle barna. Rundt 1960 holdt han et foredrag i Norsk selskap for tuberkulose og lungesykdommer hvor han redegjorde for bronkoskopiene. Frostad mente at barna ikke hadde vondt av undersøkelsene. «Ellers har jeg notert ... de tre gangene jeg tok bronkoskopi, som var en smertefull opplevelse ...,» skriver Hoftvedt.

Jeg husker at en del tilhørere ristet på hodet. Men det var ingen som protesterte. Og da Frostads artikkel ble publisert i Tidsskriftet, kom det ikke en eneste kritisk bemerkning fra landets tusener av leger. Hvorfor? Av frykt for å sette seg opp mot autoriteten? Han kunne jo ha gjort en epo-

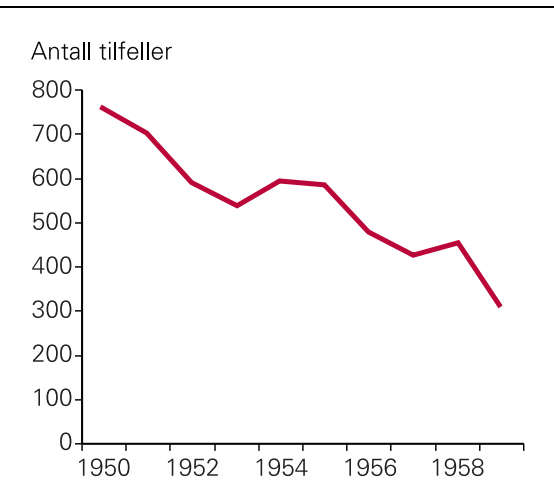

Figur 1 Meldte tilfeller av tuberkulose hos barn under 15 år i Norge i perioden 1950-59, begge kjønn samlet, etter tall fra Folkehelseinstituttets sentrale tuberkuloseregister 


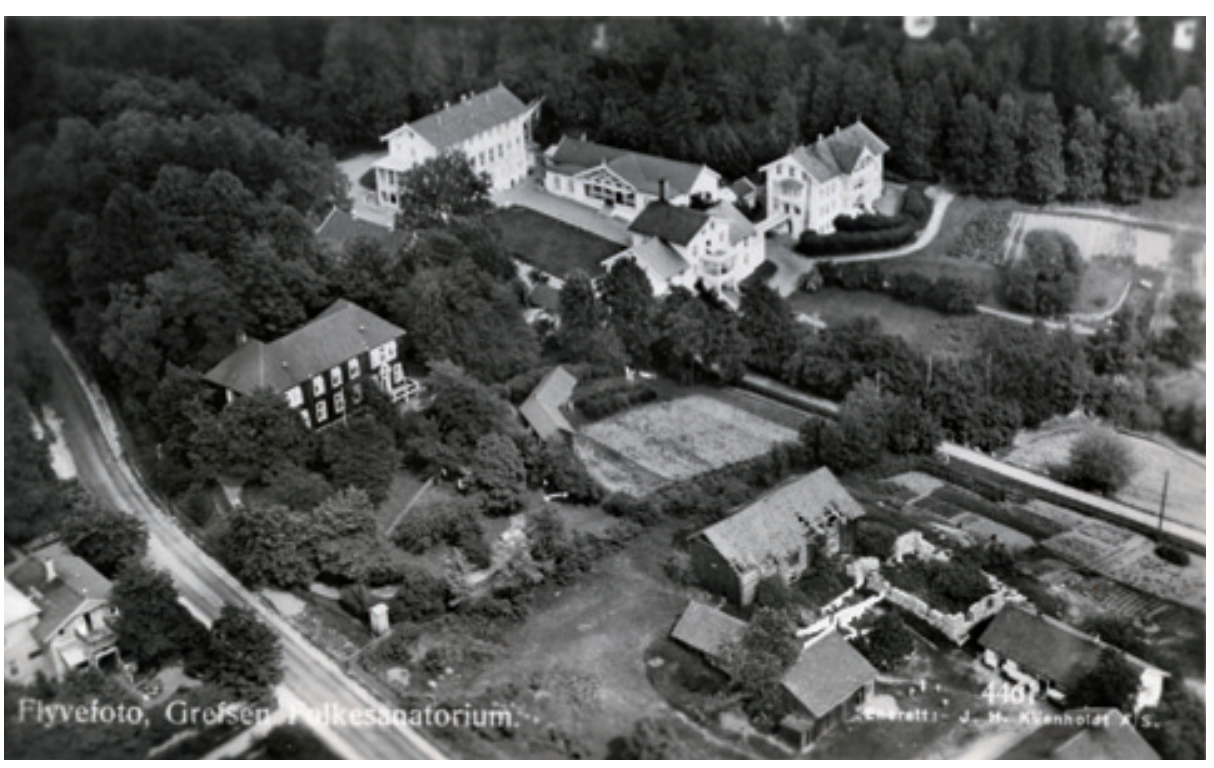

Grefsen sanatorium. Postkort fra J.H. Küenholdt, 1920-årene/Oslo Museum

kegjørende oppdagelse! Nei, jeg har ingen god forklaring. At det skyldtes manglende medfølelse med barna, har jeg vanskelig for å tro.

Frostad opplyste at det hos 11 barn hadde vært komplikasjoner - larynxødem, fordi det var brukt for store bronkoskop, og respirasjonsstans under narkosen (dog uten fatal utgang).

Ved bronkoskopiene ble det bl.a. påvist bronkialstenose hos $72 \%$ av barna og glandelperforasjon hos $35 \%$. Bare hos $4,5 \%$ ble det registrert helt normale bronkoskopiske funn. Frostads rettesnor for behandlingstidens lengde var resultatene av de gjentatte bronkoskopiene.

Hvilke konsekvenser hadde påvisningen av bronkieforandringene? Sannsynligvis ingen. Dette har utvilsomt sammenheng med at barna fikk den best mulige behandling med det medikamenttilbud som forelå, i tillegg til at hilusadenitt er en benign sykdomsform. Men også andre sykehus ga barn tilsvarende behandling - uten veiledning av bronkoskopifunn.

Frostad trodde imidlertid sterkt på betydningen av langvarige sanatorieopphold «en adekvat behandling forutsetter et opphold $i$ et sanatorium eller lignende anstalt i $1-1 \frac{1}{1} 2$ år». Bare $18 \%$ av barna ble utskrevet etter en behandlingstid på under ett år, de øvrige hadde lengre opphold. Sju av barna ble utskrevet før tiden. Hoftvedt var antakelig en av dem. Frostad var tydelig irritert: «... ikke få av disse barna er tatt hjem av sine foreldre fordi deres læge, som i enkelte tilfelle også har vært lungespesialist, ikke har skjønt hvorfor barnet blir behandlet så lenge hos oss. [...] Det virker derfor meget uheldig når barnet og foreldrene får vite at barnet trenger noen få måneders behandling i sanatorium, og det styrker ikke tilliten at man vurderer situasjonen så feilaktig.»
Bare ett av de 223 barna Frostad gjør rede for, døde av sykdommen - etter en behandlingstid på henimot åtte år. Det var ett av de fem barna der det ble påvist medikamentresistens.

\section{Sykepleiernes rolle}

Sykepleierne var bundet av de rammene Frostad hadde satt. Men de var også bundet av en annen ramme: ressurstilgangen. Det er liten tvil om at sanatoriene hadde lav status i sykehusvesenet. Bemanningen var mye svakere enn i dagens barneinstitusjoner. Og det såkalte kostøret tillot på ingen måte «fem om dagen». Sykepleierne fikk neppe tid til å ta seg av barna slik de gjerne ville, f.eks. hjelpe dem med å håndtere hjemlengselen. For å mestre oppgavene følte de seg nok tvunget til å holde på disiplinen.

Ett besøk i uken er samme frekvens som i dag gjelder for innsatte i fengsler med høyt sikkerhetsnivå. Men sanatoriets bestemmelse om besøk var ikke straff overfor barna. Trolig mente ledelsen at flere besøk bare ville gjøre hjemlengselen større og at det da ikke ville være kapasitet til å dempe savnet. At Hoftvedt fant situasjonen på Rikshospitalet mye bedre, må også skyldes at personellressursene var større der.

Jeg tror sykepleierne gjorde så godt de kunne innenfor de gitte rammene. En annen pasient, Tor Wiik, skrev nylig om tiden ved barnesanatoriet på Grefsen: «Min hukommelse er fylt med gode minner om en betjening som gjorde sitt ytterste for å la oss pasienter få leve normale liv fylt med omsorg. [...] Jeg oppfatter at sykehuspersonalet var svært selvoppofrende, ved å ta seg jobb på denne type institusjon, med fare for egen helse. De fleste var nok idealister som gikk til den vanskelige oppgaven med beundringsverdige holdninger» (8).

\section{Frigjøringen}

I 1968 kom nye medikamenter, bl.a. rifampicin. Nye behandlingsregimer ble introdusert, noe som forte til at behandlingstiden for pasienter uten medikamentresistens kunne reduseres til seks måneder og behandlingen skje ambulant.

Dette ble frigjøringen for sanatoriepasientene. Kurhallene ble revet, sanatoriene nedlagt og bronkoskopi av barn med primærtuberkulose opphørte. Samtidig gikk antall nye tilfeller ned pga. bedre levekår og planmessig smittekamp (2).

I 2008 ble det for hele landet registrert kun to norskfødte tuberkulosepasienter uten innvandrertilknytning under 15 år, ifølge Folkehelseinstituttets sentrale tuberkuloseregister.

Jeg takker Vigdis Dahl, Aage Tverdal og Brita Winje ved Nasjonalt folkehelseinstitutt for opplysninger om tuberkulosesykelighet.

Oppgitte interessekonflikter: Ingen

Litteratur

Hoftvedt BO. Sanatoriebarn. Tidsskr Nor Legeforen 2009; 129: 1015-6.

2. Bjartveit K. Hvit pest, svart tjære. Felttog mot farlige folkesykdommer på 1900-tallet. Oslo: Michael 2007; 4 (suppl 7): 19-59.

3. Bjartveit K. The tuberculosis situation in Norway. Scand J Respir Dis Suppl 1978; 102: 28-35.

4. Sunnhetstilstanden og medisinalforholdene. Med sammendragstabeller 1951-1955 og 1956-1960 Oslo: Statistisk sentralbyrå. www.ssb.no/vis/ histstat/publikasjoner/histemne-02.html?id =P909_26538\%20 (24.3.2009).

5. Gleditsch G, Bjartveit K. Belegget av tuberkuløse ved medisinale anstalter i Norge. En oversikt pr. 1. desember 1960. Tidsskr Nor Lægeforen 1961; 81: $1039-42$.

6. Larsen $\emptyset$, red. Norges leger. Oslo: Den norske lægeforening, 1996.

7. Frostad S. Diagnostikk og terapi av primærtuberkulose hos barn. Tidsskr Nor Lægeforen 1960; 80 1091-8.

8. Wiik T. Grove feil om barnesanatorium. Sunnmørsposten 28.10.2008. www.smp.no/article/ 20081028/MENINGER05/862017772 (24.3.2009).

Manuskriptet ble mottatt 23.3. 2009 og godkjent 2.4. 2009. Medisinsk redaktør Erlend Hem. 